\title{
An Analysis of Economic Philosophy and Leadership in Ancient India
}

\author{
Sushma Shukla \\ Piedmont Virginia Community College
}

Economics was a part of social and political thoughts in general for most of history. In the eighteenth century, Adam Smith saw economics as a subset of jurisprudence. However, the seeds of economic analysis were planted long before; in ancient India, societies exercised economic theories and principles during the 3rd century BCE. This paper investigates the economic leadership in ancient India between the 3rd century $B C E$ and the $3 r d$ century C.E. During that era, a philosopher, economist, jurist, and royal advisor named Chanakya authored the ancient Indian political treatise the Arthshastra. He has discussed many economic theories like economic growth, tax, and mixed economy in his book. He is considered the pioneer of political economics in India, and his work is believed to as an essential precursor to classical economics. This paper evaluates the theories of Chanakya by a comparative analysis of political and economic union between the modern-day the European Union and the Mauryan Empire of ancient times.

Keywords: economic philosophy, ancient India, economic growth, political economy, the European union

\section{INTRODUCTION}

Chanakya (350 BCE-283 BCE), also known as Kautilya, was a great brahmin philosopher, advisor, Guru (Teacher), economist, and a prime minister to the first Maurya Emperor Chandragupta (340-293 $\mathrm{BCE}$ ), and believed to be an architect of his rise to power. He was a professor at Taxila University, remains still located close to Rawalpindi, Pakistan. He is widely considered to be the founder of the first Indian empire. It is believed that Chanakya established Chandragupta Maurya as the king of India and liberated India from the king of Nanda. Chanakya assisted the young Chandragupta Maurya, a Vaishya, to ascend to the Nanda throne in $321 \mathrm{BC}$. Chanakya's counsel is particularly remarkable because the young Maurya's supporters were not as well as armed as the Nandas. Chanakya continued to assist Chandragupta Maurya and his campaigns for many years. His vision and policies influenced and were crucial in consolidating the great Mauryan empire. He has often been likened to Machiavelli (known as the father of modern political philosophy and political science) by political theorists, and the name of Chanakya is still reminiscent of a vastly scheming and clever political adviser. According to Jha and Jha (1997, pp.3-4), "Chanakya was a great statesman as well as a great scholar. He played a dominating role in the formation and functioning of the Maurya empire. Subsequently, under his guidance, growth with stability was attained in the empire with the help of strong administration and efficient fiscal management. His attainment in the sphere of scholarship is undoubtedly laudable."

The 'Arthasastra' is a treatise on Economic Administration written by Chanakya in the 4th century BC. It is a detailed analysis of different aspects of the ancient Indian economy. It consists of 15 chapters, 380 Shlokas, and 4968 Sutras. Probably, this is the first-ever book written on political economy in the world. 
Chanakya wrote the Arthashastra as a guide for "those who govern" and, as he was interested in establishing and operating the governance machinery through which the king (governing head) preserves the integrity and solidarity of the State which generates power. It is impressive to see that several economic concepts, models, and theories described in the Arthashastra, thousands of years ago by Chanakya, are still being acknowledged into present-day economic models and theories.

The purpose of this paper is to analyze the work of this great scholar and his work through some comparisons between the coverage of Arthasastra and modern thoughts on political economy and economics and then to consider Chanakya's view of the purpose of economic policies and the function of the king. It is known that Chanakya helped Chandragupta to crate the Maurya empire, which was also a political and economic union similar to the European Union in the modern era. This paper primarily focuses on evaluating the theories of Chanakya by performing a comparative analysis of the European Union and the Maurya Empire. This comparison is based on examining his views about various economic theories like the Treasury and principles of taxation, Single Currency and banking system, economic systems, international trade, the importance of national economic accounting and census data, the importance of property rights for economic activity.

\section{A COMPARISON OF THE EUROPEAN UNION AND MAURYA EMPIRE}

The European Union initially named the European Economic Community (EEC), was created in 1958 in the aftermath of the Second World War. Initially, the goal was to increase economic cooperation between six countries: Belgium, Germany, France, Italy, Luxembourg, and the Netherlands. Since then, 22 other members have joined, and a huge single market had been created and continues to develop towards its full potential. Initially, the primary goal was to build a purely economic union; later on, it evolved into an organization across other policy areas, from climate, environment, and health to external relations and security, justice, and migration. The name changed from the European Economic Community (EEC) into the European Union (EU) in 1993.

The first step of the union was to enhance economic cooperation, and the main idea was that the countries that trade with each other become economically interdependent and more likely to avoid conflict and enhance smooth trading. Now the EU aims to enable EU citizens in a wide area including but not limited to study, live, shop, work, and retire in any EU country and enjoy products from all over Europe. To do this, it ensures the free movement of goods, services, capital, and persons in a single EU internal market. By removing technical, legal, and bureaucratic barriers, the EU also allows citizens to trade and do business freely. The European Union is one of the unique economic and political unions between $27 \mathrm{EU}$ countries covering much of the continent.

Now, if we go back to ancient times and look at the Maurya Empire, it was also an economic and political union created by Chandragupta Maurya under the guidance of his prime minister Chanakya. There are many historical pieces of evidence about the Maurya empire, and the Maurya Empire was a geographically widespread Iron Age historical power. It was built in Magadha and created by the great emperor of ancient India, Chandragupta Maurya. The Maurya Empire dominated the Indian subcontinent between 322 and 185 BCE. During that time, several small counties in India were being separated from each other. The largest State was Magadha's controlled by Nanda. Therefore, its rulers were persecuted as a result of the demise of the people.

On the other hand, the self-centered elements inside the people were encroaching on the limit following the collapse of the people. At the same time, this unfriendly Brahmin entered politics and strengthened his political base from his extraordinary intellectual splendor. This led to the creation of the first historical empire, the Maurya Empire, in India, and till the fall of the Guptas, Indian rulers have been able to rule for a large number of times in India, for centuries. Chandragupta used various ways to build his empire, such as marriage alliances, diplomacy, trickery, and war, to extend his kingdom. 


\section{Geographical Area and Size}

According to the EU in brief and official website of the European Union (EU), it is a political and economic union of a total of 27 member states that are located mainly in Europe. Its members have a combined area of 4,233,255.3 $\mathrm{km} 2(1,634,469.0 \mathrm{sq} \mathrm{mi})$. The estimated total population of the European Union is about 447 million.

The Maurya empire was the most powerful political entity that has existed in the Indian subcontinent, extending over 5 million square kilometers (1.9 million square miles) (Turchin et al.) Under Chandragupta's power, the Maurya empire stretched from eastern Iran to the western borders of the Burmese hills and from the Himalayan tribal kingdom to the southern plateaus of peninsular India. Comprising the majority of South Asia, the Maurya Empire was centralized by the conquest of the Indo-Gangetic Plain, and its capital city was located at Pataliputra (modern Patna). Thapar, Romila (1990). Similar to the European Union, the Maura empire was also a group of states called janpada. However, the difference was it was controlled by a monarchy which in modern-day known as command economic system.

\section{Economic System}

European Union adopted a mixed economic system. The economic engine of the European Union is the single market in the region. It permits most goods, services, money, and people to move freely across the region. The EU aims to develop this vast resource in other areas as well. Such as energy, technology, knowledge, and capital markets to ensure that Europeans can draw the maximum benefit from it.

The Maurya Empire was a centrally planned (mixed) economic system secured by the monarchy. The king had all the economic power, but their states (Janpada) also had power. According to Megasthenes, three parallel administrative structures marked Chandragupta's rule. One managed the affairs of villages, ensuring irrigation, recording land ownership, monitoring tools supply, enforcing hunting, wood products, and forest-related laws, and settling disputes. Another administrative structure managed city affairs, including all matters related to trade, merchant activity, visits of foreigners, harbors, roads, temples, markets, and industries. They also collected taxes and ensured standardized weights and measures. (Sastri, 1988) The third administrative body overlooked the military, its training, its weapons supply, and the needs of the soldiers. (Sastri, 1988)

\section{Monetary System and Currency}

The European union's 19 member states have joined a monetary union known as the Eurozone, which uses the euro as a single currency within the member states. The currency euro represents 342 million EU citizens. The euro is the second largest reserve currency in the world. It is also the second most traded currency in the world after the United States dollar. The European union's Eurozone has its own central bank called the European Central Bank, which controls all the monetary policy within the Eurozone.

Similarly, the Maura Empire has also established a single currency across India. King Chandragupta's Prime Minister Chanakya was credited with writing a treatise in Sanskrit on statecraft and monetary policy of a kingdom in his book Arthasastra. There is strong evidence from this treatise that during that time, coins existed, denominations. Mauryan coins were very similar to the punch mark silver coins of other Early Kingdoms. However, Mauryan coins differed from others by having five punches, and they always included a symbol of the sun in those punches. Mauryan Empire also introduced square-shaped copper coins with punch marks for the first time in India.

It is clear that both of the unions had a single monetary system and a single currency system controlled by one institution.

\section{Taxation}

The European Union has no power in collecting taxes or setting up any tax rates. The tax rate, the tax amount each citizen pays, and how the collected taxes are spent are decided by their national government. The European Union does, however, oversee national tax rules in some areas; particularly concerning EU business and consumer policies, to ensure -the free flow of goods, services, and capital around the EU (in 
the single market), businesses in one country do not have an unfair advantage over competitors in another, taxes do not discriminate against consumers, workers or businesses from other EU countries.

The Maura Empire also had a taxation system. During that era, farmers comprised the most significant part of the population, and agriculture was taxed. Trades people were organized into guilds that held both executive and judicial authority and also functioned as banks. Craftspeople engaged in a particular industry tended to live together. Goods could not be sold at the place where they were produced; they had to be brought to specific markets. Tolls were collected for roads and river crossings, and goods sold within the kingdom were taxed, as were imports and exports. The State had the power to fix the wholesale price of all the goods, and they also inspected weights and measures. During that time barter system was widespread, as were gold, bronze, and copper coins. Money was lent on interest against promissory notes.

As Sarkar (1999-2000) points out, Chanakya's taxation systems are very comprehensive, but some ideas expressed about taxation in Arthasastra predate it. According to Musgrave and Musgrave (1989), many of the principles of taxation that he outlined are still in favor today, as a perusal of standard texts on public finance. Rao (1958, pp. 206-210) lists the many sources of state revenue identified and discussed by Chanakya and concludes that the State was "zealous in the collection of revenue from all possible sources so that the wealth so accumulated might be spent on the protection of the State from external and internal changes, and on social services and productive enterprises, as the building of forts, roads, plantation of colonies, of villages, asylums, orphanage, and educational institutions" (Rao, 1958, p.210).

\section{Economic Growth}

The European union's goal is to fight poverty and achieve sustainable development. The EU institutions and countries are the leading donors of development assistance and cooperation in the world. The EU legislation and policies are to promote good governance and human and economic development, such as fighting hunger and preserving natural resources in the region. The EU's policies are also to encourage the United Nation's sustainable development goals. EU institutions work together and provide funding to address the following five aspects of sustainable development: People: End poverty and hunger in all forms and ensure dignity and equality. Protect future generations from environmental destruction and resource depletion. Ensure prosperous and fulfilling lives in harmony with nature. Create peaceful, just, and inclusive societies. Implement development work through global partnership.

The Maura Empire also nourished a multi-dimensional growth model with several interrelated variables of interest (growth factors) and bi-directional causality. In his theory, it was no mystery why some Empires would register faster growth and why the others would move slower. In the Maurya empire, the central part of his model was agriculture and fishery. These were the two main sectors that generated added value and wealth for the King and the State. The mining industry was also an essential source of wealth, with its four industrial levels: state monopolies (dealt with making weapons and brewing liquors), state-controlled industries (textiles, salt, and jewelry), state-regulated small industries (craftsmen-goldsmiths, blacksmiths), and private industry (that was free, unregulated) — potters, basket makers, and others. Other types of industries are not directly regarded in Chanakya's readings. While the State is dominant in the economic system described by Kautilya and was often in the position of a privileged monopolist, cooperation between the State and the private sector was also encouraged. Kautilya was of the opinion that "a strong private sector is a course of strength to the state" (Sarkar, 1999-2000, p.65).

\section{International Trade}

The European Union is the largest trade block in the world. It is the world's biggest exporter of manufactured goods and services and the biggest import market for over 100 countries. Free trade among its members was one of the EU's founding principles. This is possible thanks to the single market. Beyond its borders, the EU is also committed to liberalizing world trade.

The Maura Empire was encouraged to trade variously. On the modern boundary of Pakistan and Afghanistan, the Khyber Pass was a strategically important port of trade and a place to interact with the other part of the world. Hellenic kingdoms and Greek states in West Asia turn out to be crucial trade partners of India. Trade also extended through the Malay peninsula into Southeast Asia. The Maurya empire 
exported silk goods and textiles, spices, and exotic foods from other parts of the world. The external world came across new scientific knowledge and technology with expanding trade with the Mauryan Empire. Later on, Ashoka, son of the Chandragupta, also sponsored the construction of thousands of roads, waterways, canals, hospitals, rest-houses, and other public works. The easing of many over-rigorous administrative practices, including those regarding taxation and crop collection, helped increase productivity and economic activity across the Empire trade and enterprise were public and private affairs the State could own and engage in business activities just like ordinary citizens could. The royal revenue was drawn from taxes (and war booty). Additionally, the king owned timberland, forest land, hunting groves, and manufacturing facilities, and their surplus was sold off. The State had a monopoly over coinage, mining, salt production, arms manufacture, and boat building.

\section{Public Goods and Services}

The European union focused on making its governing institutions more transparent and democratic. Decisions are taken as openly as possible and as close as possible to the citizen. More powers have been given to the directly elected European Parliament, while national parliaments play a more significant role in European institutions. The EU is governed by the principle of representative democracy, with citizens directly represented at the Union level in the European Parliament and Member States represented in the European Council and the Council of the EU. European citizens are encouraged to contribute to the democratic life of the union by giving their views on EU policies during their development or suggest improvements to existing laws and policies. The European citizens' initiative empowers citizens to have a greater say on EU policies that affect their lives. Citizens can also submit complaints and inquiries concerning the application of EU law.

The Maura Empire also supported many public works and waterways to enhance productivity, while internal trade in India expanded greatly due to new-found political unity and internal peace. It was the king's duty to maintain the roads and provide social assistance to their citizens. The Maura Empire At the same time, Chanakya advised the king to limit his expenditure on servants. This should be kept to less than a quarter of his total revenue. Chanakya (Shamasastry, 1961, p.276) says: "In accordance with the requirements of his parts and country parts, the king should fix under one-fourth of the total revenue the charges of maintaining his servants ........ He should not violate the course of righteousness and wealth". In essence, the Treasury does not exist for the king's pleasure but as a fund to be wisely utilized to increase the nation's wealth. Many sources of public revenue are considered by Chanakya.

\section{CONCLUSION}

The arguments and explanation in this paper show that the economic ideas of Chanakya are based on certain economic principles that can be observed in the modern era as well. It is fascinating to see that a treatise written 2500 years ago is still adoptable. That tells us how developed humans thinking was 2500 years ago. Chanakya's Arthashastra is a very comprehensive treatise on governance in a monarchical Vedic state. It contains valuable insights into political economics. Chanakya's Arthashastra provides a valuable basis for economic development. There are many elements of modern economics in Arthashastra, but only

a few aspects can be mentioned here. It was a valuable guide to political economy in its time and provided us with privileged insights into the Mauryan economic system and society.

There is a more significant difference in the time of the Maura Empire mentioned before 2500 years ago and present the European Union on the concept of an economic and political union of nations. However, there are many similarities as well. With careful reading, one can glean from it many economic pearls of wisdom of relevance to our times, and it certainly can be used to illustrate several modern economic ideas. Arthashastra is a systematic study of political economics, and it is a significant contribution to economic theory and, as such, deserves rehabilitation of its long-forgotten proper place in the history of modern economic thought. Chanakya could indeed be called the first political economist and precursor to classical economic thought. 


\section{REFERENCES}

Collignon, S., Collignon, S., \& Sangster. (2017). Governance of European Public Goods. Palgrave Macmillan.

Halpern, G.M. (2001). The Arthashastra of Chanakya, pp. 11-15

Mabbett, I.W. (1964). The Date of the Arthaśāstra. Journal of the American Oriental Society, pp. 162169.

Marshall, J. (2013). A guide to Taxila. Cambridge University Press, pp. 1-2.

Patel, R. (2020). Kautilya's Arthashastra (Economics): A Brief Historical Study. SSRN: 3513319.

Sarkar, S. (2000). Kautilya economics: an analysis and interpretation. Indian Economic Journal, 47(4), 62.

Singha Roy, S. (2018). Kautilya's 'Arthashastra' and Modern Economics. SSRN: 10.2139/ssrn.3132202

Skare, M. (2013). The missing link: From Kautilya's The Arthashastra to modern economics. Journal of Philosophical Economics, 6(2), 2-31.

Sastri, K.A.N. (1988). Age of the Nandas and Mauryas, Motilal Banarsidass. ISBN 978-81-208-0466-1

The EU in brief. (n.d.). Retrieved January 17, 2021, from https://europa.eu/european-union/about-eu/euin-brief_en

Turchin, P., Adams, J.M., \& Hall, T.D. (2006). East-West Orientation of Historical Empires and Modern States. Journal of World-Systems Research. Retrieved from http://jwsr.pitt.edu/ojs/index.php/jwsr/article/view/369

Thapar, R. (1990). A History of India (Volume 1, p.384). Penguin Books. ISBN 0-14-0138358

Tisdell, C. (2003). A Western Perspective on Kautilya's 'Arthasastra': Does it Provide a Basis for Economic Science? Economic Theory, Applications and Issues. Retrieved from https://rsmg.group.uq.edu.au/files/2137/WP\%2018.pdf

Upadhyaya, Y.M.A. (2019). Comparative Analysis of Agriculture and Economic Development of Nepal with Kautilya Arthashastra. BILLTÜRK Ekonomi ve İlişkili Çalışmalar Dergisi, 1(2), 131-149.

Waldauer, C., Zahka, W.J., \& Pal, S. (1996). Kautilya's Arthashastra: A neglected precursor to classical economics. Indian Economic Review, pp. 101-108.

Whelan, F.G. (2004). Hume and Machiavelli: Political Realism and Liberal Thought. Lexington Books, p.29. 